\title{
“IT'S ABOUT COMMUNITY” - FINDING LOCAL SOLUTIONS TO LOCAL \\ PROBLEMS: EXPLORING RESPONSES TO THE SOCIAL PROBLEM OF YOUTH UNEMPLOYMENT
}

\author{
Michael Whitham and Gemma Piercy
}

\author{
Labour Studies \\ University of Waikato
}

\begin{abstract}
The purpose of this paper is to explore the policies and practices associated with the societal 'problem' of youth unemployment. This research is primarily a case study analysis of an employment programme established in Otorohanga to address the problem of youth unemployment. The programme in Otorohanga has consistently created a situation where in recent years nobody under the age of 25 is registered with Work and Income New Zealand as unemployed. This outcome has been achieved by ensuring that local youth are either in local training programmes, in employment or in apprenticeships. In this paper we review the international and domestic literature on youth, unemployment, engagement and policies, in conjunction with interviews with a selection of key stakeholders involved in the successes of the Otorohanga programme. We argue that youth are a significant and poorly understood demographic; and that the current policies for dealing with youth unemployment, especially the emphasis on using access to the education system and the impact of neo-liberal ideologies, has had only limited success. Using insights from the interviews, we further argue that policies that draw on local, community driven solutions grounded in labour market realities, in contrast to the current education system driven policy direction, have the potential to be more successful in dealing with the problem of youth unemployment.
\end{abstract}

\section{Introduction}

The purpose of this paper is to provide insight into how youth unemployment can be reduced through an investigation into specific policies and practices. One policy initiative being utilised in the rural New Zealand town of Otorohanga is held up as an example of a successful set of projects addressing youth unemployment. It is successful in that it has consistently achieved a state of no registered youth unemployment since 2006. This paper uses Otorohanga's youth initiative as a case study to investigate which key aspects of this policy have contributed to its success. The goal is that by highlighting these aspects, they could be reproduced in other communities seeking to solve the same problem. Therefore, the over-arching research question is:

- Using Otorohanga’s youth employment initiative as an example of success, what aspects of that successful policy should and could be reproduced elsewhere in order to reduce youth unemployment?

In order to answer that research question, this paper:

- $\quad$ Explores, with an emphasis on New Zealand, the nature of youth and youth unemployment

- Examines the policies and practices utilised in New Zealand and globally since the turn of the $21^{\text {st }}$ century to resolve the problem of youth unemployment, and

- Uncovers and defines good practice elements of the Otorohanga scheme that reduce unemployment and can be integrated into programmes in other communities.

The Otorohonga programme Zero Youth Wasted that forms the focus of this investigation involves 11 initiatives that include:

- Wintec Otorohanga Trade Training Centre (OTTC)

- $\quad$ Trade Apprentice Co-ordinator

- Careers Expos

- Trade Brochures

- McDonald’s Lime Student Scholarships

- Mayoral Graduation Ceremony

- Young Achievers Awards

- Otorohanga College Gateway

- "MPowa”

- Harvest Rock Youth Centre

- $\quad$ Project Grow Oto (ODDB, 2009).

\section{Literature Review}

\section{Theoretical lens}

Currently we are in a neo-liberal, socially conservative political environment with a central government that historically sits on the right of the political continuum. However, the left, social democratic politics still have a legacy in countries such as Aotearoa New Zealand. Social democracy, as the dominant ideology for many western 
countries in the mid-20 ${ }^{\text {th }}$ century (Giddens, 1998; Sullivan, 2003), is based on the idea of state intervention to improve community, equality and equity, in contrast to neo-liberalism. Government and public ownership play a big role in shaping society and welfare is provided to enable an equal and equitable environment under a socialist or social democratic regime (Duncan, 2004; Cheyne, O’Brien \& Belgrave, 2008). One of the key features of social democracy is that of collectivism. Collectivism is seen as a major influencing construct for social democratic ideology and is "defined as a set of feelings, beliefs, behavioural intentions, and behaviours related to solidarity and concern for others" (Hui, 1988, p.i). Although radical and extreme socialism is not generally seen as an appropriate or achievable goal in the present political climate, supporters of this ideology now strive to achieve social goals through people-elected (democratic) principles and government policies that promote equality under the banner of the third way (Giddens, 1994; Duncan, 2004; Cheyne, et al, 2008). The third way concept of subsidiarity and its notions around partnership are a contemporary echo of collectivism in the modern context (Harris, 1999; Batters, 2010). For example, the creation of a tripartite relationship between government, businesses and unions occurs, which assumes an ideological understanding for balancing the needs of the economy with those of society (Giddens, 1998, 2002; Eichbaum, 1999; Harris, 1999; Piercy, 2005).

The third way has "been hyped as a new kind of politics" that is neither left nor right on the continuum of political space and is a highly contested concept (Eichbaum, 1999; Kelsey, 2002). The third way ideology can be characterized as encompassing aspects of both the left and the right discourse (Neilson, 2001). It is not a politically left, socialist discourse nor does it encourage the full market principles of neo-liberalism. Instead it sits somewhere in the centre where its intentions seem to be to create a partnership of social democratic ideas positioned in a neoliberal political environment.

The neo-liberal ideology has underpinned economic policies in many Western nations, particularly New Zealand, since the demise of social democratic policy of the 1970s and 80s. Neo-liberalism incorporates three main themes of significance to this paper. First, a minimal role of government - as the ideology assumes that state intervention prevents economic success. Instead the argument is that government exists to ensure that regular market forces can create success and economic prosperity. Second, individual responsibility, individual choice and competition - the ideological principle that assumes each person can and should fend for him/herself and that individuals and businesses should compete for financial superiority in their respective fields (Jessop, 2002; Carl, Baker, Scott, Hillman and Lawrence, 2012). Third, business profits and 'earned' money are the cornerstones of success in a neo-liberal society (Giddens, 1994; Olssen, 2002; Duncan, 2004).

Within this ideology, a deep seated assumption is that "individuals are rational utility maximisers" (Duncan, 2004, p 194) and will make choices "which balance costs and benefits in the pursuit of achieving the greatest possible outcome." In line with the theory of rational utility is the idea human capital theory (HCT) which has created economic formulas to measure the costs and benefits associated with education and employment. Under the construct of HCT, it is assumed that investment in education will ultimately provide greater gains in income. Because of the presumed capacity to increase individuals' earnings and the socio-economic rewards that are gained through education such as increased productivity, education is seen as a tool that can enhance both the individual and society. However, in a neo-liberal context, HCT is primarily focussed on the economic, rather than the social outcomes of education (Marginson, 1993; Olssen, 2002). Employment policies have utilised the concept of HCT, reshaping education to focus more on improving employability (Krause \& Vonken, 2009).

\section{Youth: Increasingly unemployed and poorly understood}

Youth as "a key indicator to the state of the nation" (Carl et al., 2012, p.66) are very important and need to be understood, particularly because the proportion of youth unemployed has been growing (ILO, 2012b). Policies are needed that focus on how to best enhance the ability of youth and prevent disengagement (Burns, Collin, Blanchard, De-Freitas \& Lloyd, 2008; Sefa Dei, 2003) and thereby improve "the state of the nation" for the present and future (Sheahan, 2005).

Youth are a disadvantaged sector of the labour market (ILO, 2006). They often lack not only work experience but also life experience due to their age. This disadvantage is exacerbated by structural inequality, such as their educational attainment, financial status and/or 'social class', and ability to be independent. For example, Hunter (1998) and Godfrey (2003) both noted that youth unemployment appears to be concentrated, though not exclusively, in lower socio-economic areas and disadvantaged communities. They also argue that youth unemployment is linked to peer, familial and social support as much as personal characteristics or labour market outcomes. Based on these structural limitations, youth are likely to accept lesser conditions than their older counterparts when starting a new job in order to get a 'foot in the door', and often do not recoup the lower wage difference throughout the rest of their working life. This is a consequence often called 'wage scarring' (Gregg and Tominey, 2005; Mroz, 2006).

Although the youth unemployment rate is often at least twice as bad as the general unemployment rate, economic downturns, and in particular the 2008 global recession, saw youth unemployment deteriorate to approximately three times worse than general unemployment. The high global youth unemployment rate of 12.6\% in 2011 (ILO, 2012b) demonstrates that the current direction of youth employment policies are ineffective.

"With nearly 75 million youth unemployed
worldwide, the youth unemployment rate has
remained close to the crisis peak in 2009, and
medium-term projections suggest little
improvement. Particularly worrisome is the
increase in those youth who have withdrawn from
the workforce, and in those who are neither in
education nor in employment." (ILO, 2012a).

"With nearly 75 million youth unemployed worldwide, the youth unemployment rate has remained close to the crisis peak in 2009, and medium-term projections suggest little improvement. Particularly worrisome is the the workforce, and in those who are neither in education nor in employment." (ILO, 2012a). 
Individuals who are unemployed face many other negative consequences that further exacerbate the social problem of youth unemployment (Jobs Research Trust, 1995; Creed \& Evans, 2001; Giddens, 2002). Some of these negative repercussions can include a feeling of social exclusion, as well as disengagement from the community, employment and education spheres. Social exclusion can lead to a loss of identity, a feeling of isolation and a reduction in social interactions and networks (Giddens, 2002; Green, 2010). As disengagement occurs, the effects on the community from youth unemployment become more noticeable. For example, youth are more likely to partake in crime or deviant behaviour, contributing to an increase in the level of social unrest within a community (Britt, 1997; Raphael \& Winter-Ember, 2001).

\section{Employability through Education}

Currently, access to education is largely used as a solution to address the problem of youth unemployment (Hillage \& Pollard, 2008; Kraus \& Vonken, 2009). Many studies have shown that youth who remain engaged in education are more likely to be employable and also remain engaged in employment (Bynner \& Parsons, 2002; Bynner, 2004). The focus on education stems from human capital theory (HCT) and the idea espoused by governments that increasing skill levels (education) will improve productivity and growth, thus increasing employment opportunities (Marginson, 1993; Olssen, 2002). Education remains a good approach to employment because it up-skills the participants and enables them to undertake a greater range of positions that may require a higher skill set (Hillage \& Pollard, 2008; Kraus \& Vonken, 2009). Furthermore, education can reduce the impact of structural inequalities because improved education can lead to upward social mobility (Giddens, 2002), thus decreasing the level of vulnerability and marginalisation within society.

Other youth unemployment initiatives that have been utilised globally and within New Zealand have involved government funded job skilling, matching and networking, training assistance, and vocational training reforms for individuals, as well as providing tax cuts for individuals, incentives for businesses and corporate stimulus packages to promote Keynesian economic style growth (Tcherneva, 2011; Hart, 2011).

\section{Case study: Regional youth employment programmes}

The main programme that was the focus of this research related to the Mayoral Taskforce for Jobs (MTFJ), which was created as a reaction to the failure of the 1994 Prime Ministers Task Force for Jobs to achieve its goal of getting all those under 25 into training or employment within 6 months by the year 2000. The MTFJ aimed to rectify this situation when it was created in 2000. The MTFJ was organised to ensure that local pathways and solutions could be used to tackle the problem. Since the initiation of the MTFJ, a number of policies have been set up in different regions that have been successful in reducing local unemployment. The MTFJ is a committee of town/city mayors in New Zealand organised to ensure that local pathways and solutions could be used to tackle youth unemployment. Since the initiation of the MTFJ a number of policies have been set up in different regions that have been successful in reducing local unemployment. These policies have included enabling national access to Youthline and the WINZ-run youth transition service, as well as local community programmes such as Otorohanga's Zero Youth Wasted policy, Work'n It Out in Southland, Link'D in Masterton, amongst others.

\section{Methodology and Research Approach}

The approach adopted in this paper is to use both qualitative and quantitative techniques to gain a thorough understanding of the topic and to provide different levels of analysis (Cresswell, 2003). This approach included canvassing relevant literature as well as semi-structured interviews and a focus group. The participants in the interviews all agreed to be identified due to their high profile roles within the programme. However, the three students who participated in the focus group are not identified and pseudonyms were created for them.

Interviews were undertaken with a selection of key officials involved in the implementation and continuation of the Zero Youth Wasted policy in Otorohanga. The community groups represented through these interviews were the District Council - with Mayor Dale Williams; the education provider - with Regional Campus Manager, Marlene Perry and student tutor, Raymond Hall; and the business community with industry networker and training supporter Ray Haley.

The focus group was held with three students studying towards a level 2 pre-apprenticeship certificate through the Otorohanga Trade Training Centre in October 2011. The students were a mixture of ages and gender, providing valuable insight into the pre-apprenticeship course being offered through the OTTC as well as a personal, insiders' view into the Otorohanga's youth policy's significance to young people.

Although only a small number of interviews were conducted, the interviewees had been involved in the programme since its inception and occupied different positions within the youth employment initiative (strategy to operational) painting a rich and in-depth picture of the scheme. For example, Mayor Dale Williams provided insight into the instigation of - and reasons behind - the programme. Due to his existing networks in the community, his interview served a second purpose as it was used to springboard into the snowball sampling method in order to provide the names of the other key informant participants: Marlene Perry (who has since left her job), Ray Haley and Raymond Hall. Due to his relationship with the students, Raymond Hall's interview helped identify students from one of the schemes who were willing to participate in this research. The three youths who participated in the focus group provided insights around their experiences of participating in the scheme and how they think the programme affects them.

The snowball technique was used due to the researcher's lack of understanding and familiarity with the case study site, Otorohanga. It is important to note that this method 
can create a bias in the sample as those people who are provided as potential participants are from the same social group and may hold similar perspectives (Davidson \& Tolich, 1999).

\section{Findings}

The findings from the interviews were grouped in themes of 'Otorohanga context', 'policy and funding', 'people and practice', and 'community spirit', which together portray the key role of support, community inclusion, and provision of local solutions to achieve success in reducing youth unemployment. Specific points made by different key informants are indicated by use of their name either in parentheses or in the text.

The themes taken from the students' statements in the focus group were 'desire for success', 'multiple options and choices', 'community support and expectations', and the 'OTTC's points of difference.' The points made by the different students are indicated by the pseudonyms in parentheses at the end of each quote.

\section{Interviews}

\section{'Otorohanga context'}

In the early 2000s the then-incoming Mayor, Dale Williams, wanted to drive economic development in the community and create a town that had thriving businesses and an engaged society. Marlene Perry explained that businesses wanted to stay in the community, yet they were spending "20 grand-plus a year to import people from elsewhere" due to a shortage of skilled workers. This was occurring because Otorohanga was a community where over $40 \%$ of the local population had no formal qualifications and 5.5\% were unemployed as at the 2001 Census of Population and Dwellings. After speaking to local businesses and a number of youth groups, Williams and others got together to think of ways to get skilled people in the community, and in turn, ensure that businesses and industries continued in the region.

\section{"We were in the middle of skill shortage days back then and I had a number of my large employers say to me socially they might consider relocating if they couldn't get access to more staff, particularly youngsters... and I said "we've got a pool of young people here who want to stay here"... and they said "[but] they're just not ready for work" (Williams).}

It was this conversation between Williams and the local employers that started the programme. The business community needed skilled workers and "the community decided, led by me, (Dale), that it would step into that space between the school and the employers” (Williams).

\section{'Policy and funding'}

In order to try and fix the issues, research was undertaken - funded by the North King Country Development Board - to investigate what the local employers required, what the apprentices were doing, and what training gaps existed. This research enabled the Mayor and other interested parties to know, with confidence, what the

Labour Employment and Work Conference 2012 businesses in Otorohanga needed from the community and its leaders and what the community's assets were in terms of trained and qualified people.

Williams' passion for youth and his community meant that he guided a community process of decision making that would not "focus on finding an easy pathway or a cheap pathway or a convenient pathway but [instead] decided we would own that space and do whatever is necessary to bridge the gap" and get local youth employed locally (emphasis added) (Williams).

Doing whatever is necessary comes at a cost; Williams explained that the initiative is "successful now, we've got a lot of support and we have great partnerships" but that the hurdles were huge "in the first three years" (Williams). Ray Haley further explained that the funding was "like shotgun pellets." This was a reference to the piecemeal way in which the initiative was funded. For example, the costs of the programme were funded using contracts with Wintec, and the Motor Industry Training Organisation (MITO) and well as funds provided by the ODDB and Ministry of Social Development, "Rotary, Lions clubs [and] a lot of donations.” (Haley)

There are a number of projects linked into this Zero Youth Wasted, but not all of them are successful. For example, “the art centre didn’t work” explained Williams, so it was abandoned, whilst many other projects were altered to accommodate the changing environment and funding levels.
"We've got 11 programmes currently and they're changing all the time... most of what we do is around our trade training centre where the employers design the courses... we get our employers to approve [the courses] then we put pressure on them to employ the graduates and run employment guarantees" (Williams).

Eleven initiatives are currently running because "every time we encountered what we saw as a gap we then thought about it... and set out to (fix) them". For example, Williams adds, "the key components to this (initiative) is to constantly stocktake any asset we have in our community" (Williams) including the students. "Through the year, we start matching them (the students) up with the jobs that are getting created" (Haley). They also identify what the community needs in terms of training: "We don't allow them to teach anything in our polytech that is airy-fairy or that doesn't lead to something... our [courses] are endorsed by the local economy”. (Haley)

The needs of a community vary from one location to the next, so "government programmes or schemes (which) operate on a one-size-fits-all” agenda do not work as that approach “doesn't fit anybody... What works here, works only here... I'm a very strong advocate for local solutions to local problems” (Williams).

\section{'People and practice'}

The interviewees all indicated that it is context and the people that provide the point of difference for Zero Youth Wasted's success. Marlene Perry explained the core aspect of any successful initiative is: "passion, passion, passion... a passion for the marketing, passion for the money and passion for the content..." she went on to 
explain that the co-ordinators of this initiative all have something in common:

"We're not nine to fivers, we've always taken a project view of this, and we've all got a passion for it... we want to see it through" (Perry).

This passion is illustrated by the dedication and commitment that the interviewees show towards the goal. For example:

"I'm not an official apprentice co-ordinator. I'm called a local apprentice co-ordinator... They operate at a different level to what I do. So what I do, I help them with study; nights they come in here, I give them literacy, numeracy support, I go into their jobs. And I help them gather all the practical evidence so all the things they can't do themselves or nobody's trained them to do - I help them with that. It's a lower level apprentice coordinator, really. It's more of a support role." (Haley).

\section{'Community spirit'}

Mayor Williams stated, "in communities, people just expect what they expect" and he wanted to change that. After having meetings with local groups, Williams realised:

\section{"People were saying different things but wanting the same outcome... it was simply, how do we stop our businesses leaving and how do we give out kids who wanna stay a chance?" (Williams)}

Based on this insight Williams and others ensured that the programme involved collaboration from different groups in the community. The local high school provides leavers' details to the local youth support initiative, MPowa, and employs people specifically to provide careers advice. The local church leaders provide a youth group and social setting for youth and maintain the school leavers database through the MPowa initiative. Recognition ceremonies and scholarships have been set up by the district council and local community groups. Finally, the relationships with the employers and local businesses mean that even if the:

“... employer might not have any work or might not be looking for someone, they'll agree to it (employing someone) 'cause they know this is what we do and it's a bit of short term pain for long term gain” (Williams).

He further explained, "almost every community has a youth centre... some have a polytech or a PTE ...some have graduation ceremonies... what is a little bit unique here is that ours (the initiative projects) are all connected... It's very much a whole of community awareness.” (Williams)

\section{Focus Groups}

\section{'Desire for success'}

Throughout the interviews the students displayed - and spoke of - their desire to succeed, not only for themselves but for their community. Eric noted "no one wants to work at McDonalds for the rest of their life..." and explained "you can get a better job if you do this course." (emphasis added). They believe the success will come through education with Caleb explaining that he wants success by "getting something (qualifications) under my belt to go back to." The qualifications they get from taking part in the Otorohanga initiative ensures they can succeed anywhere. Caleb stated "if you don't get a job at the end of the year, you've still got the certificate so you can go to other places.” Judy and Eric further identify their desire for success in relation to engagement: "why be on the dole and do nothing when you can be doing something and actually earning the money.”

\section{'Multiple options and choices'}

Prior to commencing the pre-trade qualification the interviewed students all had multiple options and choices for their future, whether it was to join the military (Judy), to undertake a different apprenticeship (Eric), or to return to secondary school (Caleb); however each chose to start the course. Within the pre-trade training offered by OTTC, Judy explained "you can have a look at both (automotive and engineering industries) and have an introduction to both" which further outlines the options and choices available to these youths. After the course, the options and choices continue. Although the programme is geared to helping the local community, the students are by no means restricted to staying in the district. The vocational skills they learn are based on community labour market trends but the generic skills that are learnt are transferrable to other locations. Apprenticeship options are often found for the students by Ray Haley (the apprentice co-ordinator) throughout “Te Awamutu, Otorohanga and Te Kuiti”.

\section{'Community support and expectations'}

The support that the students get comes from their family, the OTTC educators and the community environment in Otorohanga. Eric explains that support from the training centre is paramount to their success: "Ray (Haley) is always looking for apprenticeships and jobs and places for us to work after we've finished all this stuff”. Eric elaborated, explaining Mayor Williams introduces them to community members as "the kids from the training centre". Judy confirms this level of support, stating, "I think half of us would fall over" if it was not for the support. Because of the size of Otorohanga, "everyone knows everyone... [support is out there so] it's up to you if you want to get help." This support is appreciated by the students. For example, Judy states that she will "definitely pay back the community" and stay for two to three years after her apprenticeship.

\section{'OTTC's points of difference'}

The students provided insight into how they believe the OTTC is different from other training providers. Although a factual comparison was not carried out investigating these differences, the students' beliefs were noted to further understand the OTTC project. Judy stated "my brother did the course in Hamilton and from my understanding it's a lot different" due to the size of the institution, funding and amount of support. Eric noted another point of difference is the community atmosphere within both Otorohanga and the trade training centre: "the whole town, the actual whole town is working as a team to sort of do this course, all the businesses pitch in like, money and stuff." 
Thu the main reason that the OTTC works and the biggest point of difference according to the youth is "because all the businesses are involved in it (the policy)... (Eric) [And] 'cause everyone knows everyone.” (Caleb) This initiative does more than teach vocational skills to local youth; it also reengages them with employment, the community and encourages them to want to succeed.

\section{Discussion}

The findings provide rich information that enables the good practice aspects of the OTTC initiative to be identified. We argue that the role of neo-liberalism as a political ideology contributes to the inability of current policy to alleviate the social problem of youth unemployment. Neo-liberalism does this by limiting the types of policies that can be implemented and therefore limiting their effectiveness in alleviating the problem. For example, the neo-liberal focus on individual responsibility ignores structural inequality and assumes youth have the agency to resolve their own problems. This is often not the case due to youths' more vulnerable position in society that stems from their lack of skills, knowledge and experience. In addition, within the neoliberal agenda, access to education is largely used as a solution to address the problem of youth unemployment. The focus on education stems from human capital theory (HCT) and the idea espoused by governments that increasing skill levels (education) will improve productivity and growth, thus increasing employment opportunities. We agree that the road to improved employment options may well lie in education, however, this 'solution' is limited. These limitations stem from the fact that educated people may remain unemployed or underemployed if job opportunities are not available or poor matching occurs. Based on this argument, we claim that no current policy understands or specifically addresses the needs of youth directly and therefore the social problem of youth unemployment will continue.

In order to alter this undesirable situation, based on the success of the Otorohanga policy initiative, we argue that policy should be specific to the grass roots context of the social problem. For example, like the initial research used in the development of the Zero Youth Wasted programme policy should ideally investigate and identify the type, level and location of unemployment By doing so then the policy solutions developed can be better matched to the needs of the community. If this step is taken, then the policy requirements of unemployed youth can more specifically be met. This is in line with the third way argument that local, community driven solutions, grounded in labour market realities can be successful in reducing the social problem of youth unemployment. Local, grass-root initiatives can best develop tailored labour market policies, and therefore programmes should be regionally based. This pushes policy away from a onesize-fits-all approach and provides a basis by which youth can become more involved with their local social networks, which has potential to increase their social engagement. If these measures are followed, the social problems associated with youth unemployment can be addressed, which further leads to greater social cohesion at a community level.

\section{Limitations of the Programme}

While Otorohanga has been very successful in reducing youth unemployment, there are some limitations that may reduce its effectiveness in other locations. Firstly, the geographical location of Otorohanga means that it is a rural town that primarily needs to be self-sufficient. This has helped drive Otorohanga to create local services and identity. This drive may not manifest in rural locations that are in closer proximity to urban centres. Secondly, economies of scale tend to operate in larger regions that hinder the creation and success of small businesses. When there are more businesses in a larger location, often there are larger economies of scale meaning that services are better able to more efficiently meet the needs of the population. However, the unemployed population can also more often outstrip the number of jobs, training places or apprenticeships available. But if a constant stocktake of people, employment vacancies and skills were to happen, similar to the Otorohanga initiatives, this limitation could be reduced.

Finally, consequences from the pressures of the profit motive on firms in other regions could prevent this type of programme working in other areas. A number of the businesses in Otorohanga will, if necessary and possible, over-employ to ensure that youth are not unemployed based on community goodwill. They will employ additional youths because the policy initiative has engrained this impulse in the community psyche. This social responsibility is at odds with the neo-liberal emphasis on individual responsibility and the profit motive. Given neo-liberalism is hegemonic in New Zealand, transferring this sense of social responsibility may not be possible. However, all interviewees believe this is a programme that can work anywhere, and that it is the people and their passion that makes success possible. They do not believe the policy can be replicated exactly, and we concur. Different locations have different requirements; however, the principles of community, support, and matching skills with what is needed in the community are something that can be replicated. According to Williams, "larger cities are just collections of suburbs the same size as Otorohanga," and if it can work there, it can work anywhere.

\section{Conclusion}

This paper has highlighted the problem of youth unemployment in New Zealand and examined and critiqued a case study of a successful initiative being utilised in the South Waikato town of Otorohanga. The paper has explained why youth are important, and why educating and employing them is beneficial for themselves and society. This research has added to the knowledge base of youth unemployment and has provided an example of good practice in relation to the development and implementation of the Zero Youth Wasted programme. In the words of Mayor Williams, "it's not rocket science" since good practice solutions for youth employment can be developed based on support, education, providing skills for the community, and community ownership. 


\section{References}

Cresswell, J. W. (2003). Research design: Qualitative, quantitative, and mixed Method approaches (2nd ed.). Thousand Oaks, CA: Sage.

Davidson, C., \& Tolich, M. (1999). Social science research in New Zealand: Many paths to understanding. Auckland, NZ: Pearson Education.

Duncan, G. (2004). Society and politics: New Zealand social policy. Auckland, NZ: Pearson Education.

Edgell, S. (2006). The Sociology of Work. Continuity and change in paid and unpaid work. London, UK: Sage publications

Eichbaum, C. (1999). 'The politics and economics of the third way'. In S. Chatterjee, P. Conway, P. Dalziel, C. Eichbaum, P. Harris, B. Philpott, \& R. Shaw (Eds.), The new politics: A third way for New Zealand (pp. 33-62). Palmerston North, NZ: Dunmore Press.

Giddens, A. (1994). Beyond left and right: The future of radical politics. Cambridge, UK: Polity Press.

Giddens, A. (1998). The third way: The renewal of social democracy. Cambridge, UK: Polity Press.

Giddens, A. (2002). Sociology. Cambridge, UK: Polity Press

Godfrey, M. (2003). 'Youth employment policy in developing and transition countries - Prevention as well as cure' (Discussion paper 2003-320). Retrieved from http://siteresources.worldbank.org/SOCIALPROT ECTION/Resources/SP-Discussion-papers/LaborMarket-DP/0320.pdf

Green, F. (2010). 'Unpacking the misery multiplier: How employability modifies the impacts of unemployment and job insecurity on life satisfaction and mental health.' Journal of Health Economics, 30(2), 265-276. doi: 10.1016/j.jhealeco.2010.12.005.

Gregg, P., \& Tominey, E. (2005). 'The wage scar from male youth unemployment'. Labour Economics, 12(4), 487-509. doi:10.1016/j.labeco.2005.05.004

Harris, P. (1999). 'Rogernomics, the "Washington Consensus” and New Zealand economic policy'. In S. Chatterjee, P. Conway, P. Dalziel, C. Eichbaum, P. Harris, B. Philpott, \& R. Shaw (Eds.), The new politics: A third way for New Zealand (pp. 33-62). Palmerston North, NZ: Dunmore Press.

Hillage, J., \& Pollard, E. (1998). 'Employability: Developing a framework for policy analysis'. Retrieved from Institute of Employment Studies website:

https://www.education.gov.uk/publications/eOrder ingDownload/RB85.pdf

Hoare, P, N. \& Machin, M A. (2009). 'Some implications of the psychological experience of unemployment.' Australian Journal of Career Development (18)3, 57-61.
Hui, C.H. (1988). Measurement of individualismcollectivism. Journal of Research in Personality 22, pp. 17-36

Hunter, B. (1998) Addressing youth unemployment: Re-examining social and locational disadvantage within Australian cities. Urban Policy and Research, 16(1), 47-58.

International Labour Organisation. (2006). 'Global employment trends for youth'. Retrieved from http://www.ilo.org/wcmsp5/groups/public/@dgrep orts/@dcomm/documents/publication/wcms_0776 64.pdf

International Labour Organisation. (2011b). 'Global employment trends for youth:’ 2011 update. Retrieved from http://www.ilo.org/wcmsp5/groups/public/--ed_emp/---emp_elm/--trends/documents/publication/wcms_165455.pdf

International Labour Organisation. (2011a). 'Youth unemployment'. Retrieved from http://www.ilo.org/employment/areas/youthemployment/lang--en/index.htm

International Labour Organisation. (2012). Global employment trends for youth 2012'. Retrieved from http://www.ilo.org/wcmsp5/groups/public/--dgreports/--dcomm/documents/publication/wcms_180976.pdf

Jessop, B. (2002). 'Liberalism, neoliberalism, and urban governance: A state- theoretical perspective'. Antipode, 34, 452-472. doi: 10.1111/14678330.00250

Jobs Research Trust. (1995). 'Unemployment: A mental health issue'. Retrieved from http://www.jobsletter.org.nz/jbl02410.htm

Kelsey, J. (2002). At the crossroads: Three essays. Wellington, NZ: Bridget Williams Books Limited.

Kraus, K., \& Vonken, M. (2009). 'Being employable and competent. Investigating the new imperative from a comparative perspective'. In A. Heikkinen \& K. Kraus (Eds.), Reworking vocational education: Policies, practices and concepts. Bern, Switzerland: Peter Lang.

Marginson, S. (1993). Education and public policy in Australia. Melbourne, Australia: Cambridge University Press.

Mayors' Taskforce for Jobs. (n.d.). History. Retrieved from

http://www.mayorstaskforceforjobs.co.nz/history.h tm

Mroz, T. A. (2006). The long term effects of youth unemployment. The Journal of Human Resources, 41(2), 259-293.

Neilson, D. (2001). 'Left, right, third way' (Conference Paper). Paper presented at NZPSA conference at Massey University.

Olssen, M. (2001). The neo-liberal appropriation of tertiary education policy in New Zealand: 
Accountability, research and academic freedom. Wellington, NZ: Massey University Printery.

Otorohanga District Council. (2011) Youth programmes. Retrieved from http://otorohanga.co.nz/youth-programmes.html

Piercy, G. (2005). 'Riding the knowledge wave: An examination of recent work-based learning in New Zealand.' 4th International Conference on Researching Work and Learning. University of Technology, Sydney, 11 to 14 December 2005, Sydney, Australia.

Powell, M. (2000). New Labour and the third way in the British welfare state: A new and distinctive approach? Critical Social Policy, 20(30), 39-60. doi: 0.1177/026101830002000103

Raphael, S., \& Winter-Ebmer, R. (2001). Identifying the effect of unemployment on crime. Journal of Law and Economics, 44(1), 259-283.

Sefa Dei, G. J. (2003). Schooling and the dilemma of youth disengagement. McGill Journal of Education, 38(2), 241-256.

Sheahan, P. (2005). Generation y: Surviving (and thriving) with generation $y$ at work. Victoria, Australia: Hardie Grant.

Sullivan, M. (2003). 'The social democratic perspective'. In P. Alcock, A. Erskine \& M. May (Eds.), The student's companion to social policy (2nd ed.) (pp. 85-91). Malden, MA: Blackwell.

Tcherneva, P. R. (2011). 'Fiscal policy effectiveness: Lessons from the great recession'. (Levy Economics Institute Working Paper no. 649). Retrieved from Social Science Research Network: http://papers.ssrn.com/sol3/papers.cfm?a bstract_id $=1760135$ 